\title{
9 \\ Defending the Inheritance: The SDL and the 2006 Election
}

\author{
Alumita Durutalo
}

Durutalo, A. 2007. Defending the Inheritance: The SDL and the 2006 Election. In J. Fraenkel and S. Firth (eds), From Election to Coup in Fiji: The 2006 Campaign and Its Aftermath. Canberra and Suva: ANU E Press and Asia Pacific Press, IPS Publications, 78-88.

Republished with the kind permission of ANU Press.

Only five years after its birth, the Soqosoqo Duavata ni Lewenivanua (SDL) won a second general election on the basis of a promise to unify indigenous Fijians. The SDL's victory in Fiji's 2006 election signified an extraordinary achievement. The party showed that it had successfully inherited the mantle of its mainstream Fijian precursors, in the process renewing and reviving an ideological orthodoxy inherited from the Alliance Party and the Soqosoqo ni Vakavulewa ni Taukei (SVT). All three parties proved able to capture the majority of Fijians' votes. In each case, ascendancy has been founded on successfully upholding platforms based on the trinity of vanua, lotu and matanitu (defined and discussed below). This chapter explores the emergence of the SDL after the crisis of 2000, the party's election strategies, its merger with the Conservative AllianceMatanitu Vanua (CAMV), the role of the Methodist Church, and the way in which the party is influenced by the traditional politics of the vanua. 
It concludes that, in 2006, the ideology of vanua, lotu and matanitu once again unified indigenous Fijian support behind the party most Fijians identify as being on their side.

\section{The Formation of the SDL}

The SDL party was formed after a period of severe division amongst Fijian leaders occasioned by the coup of 19 May 2000. It was intended to fill a power vacuum within Fijian society and within mainstream Fijian politics. Although the newly emergent Fijian party differed in some respects from its predecessors, in its core philosophy it continued a long journey that was started by the Fijian Association in 1956. The Alliance Party had advanced an orthodoxy of vanua, lotu and matanitu between 1967 and 1987, and a similar fundamental ideological framework became the bedrock of the SVT from 1992 to $1999 .{ }^{1}$ Like its predecessors, the SDL emerged as an eastern Viti Levu-based and Vanua Levu-based Fijian political party. As with its predecessors, the link with the all-Fijian provincial councils provided the critical organisational underpinning for the party, and the backing of the Methodist Church proved of fundamental importance to the party's success.

The formation of the SDL was inspired by the need to unify indigenous Fijians once again under a single political umbrella, after the decimation of the SVT at the 1999 poll. That fracturing of the Fijian vote had ensured victory for the Fiji Labour Party (FLP)-led coalition in 1999, although that government lasted only a year. In the wake of its overthrow in May 2000, the Republic of Fiji Military Forces installed an all-Fijian 'interim' administration. Led by prime minister Laisenia Qarase, that interim government reconstituted itself as the SDL in the run-up to fresh elections held in August 2001, in the process reviving the staple orthodoxies of Fijian rule. The 2001 organisational structure of the SDL is shown in Figure 1.

1 The Alliance Party was not a Fijian party in quite the same sense as were its successors. While it relied primarily on the Fijian Association and on the votes of Fijians, it was nonetheless a coalition of different groups, and had substantial Indian support during the 1970s. 


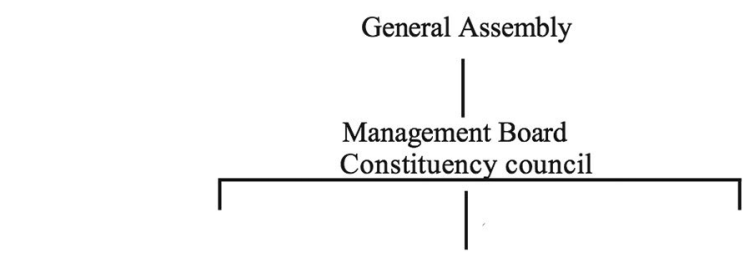

Village/Tikina Branches Settlement Branches Urban Branches

Figure 1. Organisational Structure of the SDL party.

Source: Constitution of the Soqosoqo Duavata ni Lewenivanua (SDL) United Fiji Party (UFP): 2-3.

The SDL proved a well-organised and well-funded Fijian political party from its inception. It was dominated by educated middle-class Fijians, of whom current prime minister Laisenia Qarase is an outstanding example. Qarase and other ministers in the 2000-01 interim government might instead have joined or taken over one of the already existent Fijian parties, such as the SVT or the Fijian Association Party or, most likely, the Veitokani ni Lewenivanua Vakarisito party. But these were all parties in decline, and Qarase eventually chose instead to forge a new party. From the start, the party faced a new rival, the CAMV, which was formed before the SDL. Perhaps the CAMV's close association with supporters of the Speight coup was a reason that Qarase preferred to form a different and seemingly neutral Fijian party to unite indigenous Fijians. However, the CAMV became successful in its own right, especially in Vanua Levu and in Tailevu North, Speight's power base.

Due to the similarities in political vision between the SDL and CAMV, after the 2001 election, the two parties coalesced and formed government between 2001 and 2006. Both parties stressed the need to address longstanding Fijian development problems, which they believed contributed to political instabilities in Fiji. The CAMV believed that Rabuka, as SVT government leader between 1992 and 1999, had not delivered on his 1987 coup promises to indigenous Fijians. Initial support for the formation of the CAMV was concentrated in the various vanua of the provinces of Cakaudrove, Bua and Macuata on Vanua Levu. Later, an invitation to join the party was extended to George Speight's supporters on Viti Levu. The CAMV was formed: (i) to ensure that Fiji would always be controlled by indigenous Fijians, and to incorporate that requirement 
into the constitution; (ii) to strengthen affirmative action for indigenous Fijians; and (iii) to introduce legislation to enable indigenous Fijians to be in full control of the development of their resources (Durutalo 2005).

The SDL had similar goals, but its early advantage was a more practical strategy for accomplishing these and a greater respectability (at least insofar as the link with the coup instigators was less clear). The SDL attempted to address Fijian issues through what it termed the Blueprint for Affirmative Action for Indigenous Fijians and Rotumans, which became a major plank of the party's 2001 manifesto. The 2001 SDL party manifesto explains affirmative action as:

Special programmes of assistance to help remove the economic differences between the Fijians and other communities ... these are ... provided for in the constitution ... At the moment the Fijians are falling behind in education, the professions, business and income ... the affirmative action blueprint is about our vision of a country where different ethnic communities live in peace, harmony and prosperity. It is about creating a foundation for a stable and prosperous Fiji. It affirms our commitment to securing basic economic rights and a fairer division of wealth ... inequities and inequalities ... pose a threat to our social stability. Failure to address these would put society at peril and deny social justice to a large section of the population (Manifesto Summary 2001).

The point of convergence between the SDL and CAMV that led to their coalition between 2001 and 2006, and their merger prior to the election in 2006, was their common vision that addressing Fijian economic underdevelopment was a prerequisite for Fiji's future political stability. The overall SDL vision of a Fiji of 'peace, harmony and prosperity' could only be achieved by first finding solutions to critical Fijian under-development problems.

\section{Background}

Many Fijian political parties were formed between 1960 and 2006, reflecting regional cleavages and the sociopolitical diversity of Fijian society. However, the three most powerful ones, which emerged and were consolidated mostly in eastern and northern Fiji, but were usually weaker in western Viti Levu, were the Fijian-dominated but multi-ethnic Alliance Party, formed in 1965; the SVT, formed in 1991; and the SDL, formed in 2001. After the two military coups in 1987, the SVT emerged to replace 
the Alliance and, subsequently, in 2001, the SDL emerged to replace the SVT. The parties have all given expression to a political ideology that proclaims the virtues of Fijian political paramountcy and unity. ${ }^{2}$

The three Fijian political parties sustained the dominance and ideological orthodoxy of the eastern and northern chiefdoms. The concepts of vanua, lotu and matanitu, upon which the orthodoxy was founded, have to be understood in terms of Fijian political evolution since the 19th century. Vanua identifies and demarcates a geopolitical boundary within which Fijian cultural practices and chiefly rule prevail. Lotu, meaning the new post-1835 Christian religion, replaced various forms of traditional Fijian religion and became grounded in the vanua. Matanitu is a Fijian word that denotes traditional government, and is associated with the country's three confederacies: Kubuna, Burebasaga and Tovata. Linkages between the vanua and paramount confederacy chiefs give political parties traditional sources of authority for indigenous Fijians. Legitimacy and recognition were enhanced by the employment of some eastern and northern chiefs in the colonial native administrative system of indirect rule. Matanitu became a symbol of the respect for authority and the new rule of law.

The dominance of the eastern chiefs was evident in appointments to the Legislative Council between 1904 and 1960. These were also the leaders behind the formation of the Fijian Association in 1956. This organisation, which obtained around 75 per cent of Fijian support in its 30 years of existence, was formed to counter Indian demands for a common roll. ${ }^{3}$ In the 1950 s and 1960s, the divergent political demands of Fiji's three largest communities shaped the process of decolonisation. On one hand, Fijians demanded the paramountcy of their interests. On the other, Indians wanted political rights that emphasised equality and were non-discriminating. In the middle, Europeans were adamant that their privileges be preserved and their special position be maintained (Ali 1986:9).

While other Fijian parties have tried to embody these three pillars in their party identity in one way or another, the Alliance Party, the SVT and the SDL have successfully maintained the orthodoxy as a common rallying

2 I argue that the Alliance, the SVT and the SDL parties depict a version of Fijian paramountcy in order to unite the diverse sociopolitical groups of Fijian society. The chiefdoms in eastern and northeastern Fiji are similar to the hierarchical Polynesian types of chiefdoms, while those in western Fiji, where chiefs are regarded as 'first amongst equals', are more egalitarian.

3 The common roll would have allowed for a one-person-one-vote electoral system. 
point for their Fijian supporters. During the era of the Alliance (1967-87) and in the first half of SVT leadership (1991-94), political unity under the vanua, lotu and matanitu were accepted as givens within Fijian society. Challenges by Western-based political parties in the early 1960s were not extensive enough to pose a threat to chiefs in the Alliance Party.

The formation of the FLP in 1985 and then the defeat of the Alliance Party in 1987 posed the first direct challenge to the orthodoxy. After the post-1987 coup formation of the SVT — another party intended to unify all indigenous Fijians under one umbrella — other Fijian parties, like the Fijian Association and the Veitokani ni Lewenivanua Vakarisito (VLV), emerged to pose a further challenge to the orthodoxy. The challenge intensified after George Speight's attempted civilian coup in 2000, in the sense that the coup leader did not readily accept the pronouncements of the Great Council of Chiefs. Rabuka's SVT had ushered in a new era in Fijian politics. In the process, the ideology of vanua, lotu and matanitu was modified.

Although the Council of Chiefs did not directly back the SDL party in the way that it had explicitly backed the Alliance Party and the SVT, support for the party emerged through the co-option of vanua chiefs as well as through the Methodist church-as part of the lotu ni vanuaand through individual support. The party continued to express the collective political aspirations of the majority of indigenous Fijians as their representative in modern politics.

\section{SDL Strategy for the 2006 Election}

The SDL's principal objective of achieving 'Fijian unity' was, perhaps inevitably, not achieved. But the party's biggest achievement in this direction was its ability to persuade its coalition partner, CAMV, to join the SDL. The merger occurred on 17 February 2006, although a number of CAMV members and supporters did not sanction the move. Some supporters on Viti Levu complained that they were being marginalised by the Lau islanders in the SDL party. ${ }^{4}$ Yet, the newly combined party

4 In my discussion with some of the disgruntled members on the day of the merger, they voiced their concern about the way those in the top management of both parties forced the unity on grassroots supporters. There were quite a number of members from Tailevu North, for example, who voiced their concern about the future of their demands, such as the release of George Speight, in the new SDL party. 
proved successful in retaining under the new umbrella all six of the seats won by the CAMV in 2001. With 80 per cent of the overall Fijian votes, and 36 out of the 71 seats, the strategic readjustment of indigenous Fijian politics proved successful.

\section{Strategic Methodist Church Alliance}

Central to the structure of the SDL was the use of lotu as a powerful uniting force amongst indigenous Fijians. The SDL emphasised the lotu and Christian morality as political virtues in its 2006 candidate line-up. Candidates seeking SDL nominations were required to show evidence of adherence to family values. Additionally, as seen in the curriculum vitae of a number of candidates, a number were Methodist lay preachers in their own churches. ${ }^{5}$ While direct chiefly leadership in Fijian party politics has declined since 1987, the emphasis on the lotu, uniting both chiefs and commoners, was a most important factor in SDL victory at the 2006 election. The same strategy was attempted by the VLV in 1999, but it was able to secure only around 20 per cent of the overall 1999 Fijian vote. The key difference was that, in the intervening years, the SVT had collapsed, leaving space for a new Fijian party to emerge.

In the SDL primary elections for the 2006 election, Methodist Church membership was considered an important yardstick by which to measure a candidate's sense of morality and commitment to societal development. In large urban centres like Suva, where Fijians from the rural areas have relocated to work, and where the influence of the vanua is not as strong, the church was used to identify SDL candidates for the 2006 election. For example, within the Samabula Tamavua Open constituency, leaders of the local Methodist churches in the area-including Vunivau, Samabula East, Raiwai and Raiwaqa - were in charge of local applications for the primary elections. After the primary elections in each constituency,

5 For example, Ratu Peni Volavola, one of the two SDL candidates in the Suva City Urban constituency, stated that he had been a lay preacher since 1980; church steward in the Samabula East Methodist Church since 1999; representative to the 2006 Methodist Bose ko Viti conference; and member of the Methodist Church of Fiji Working Committee. Likewise, the curriculum vitae for Misaele Weleilakeba stated that he was a confirmed lay preacher in the Methodist church and chairman of the Raiwai Methodist Church Financial Committee. See also the curriculum vitae for Ratu Mosese Volavola and Misaele Yadraca Weleilakeba, also SDL candidates in the 2006 election (in the personal collection of the author). 
the winning candidate's name was submitted to the management board, which had the final decision on SDL candidates for each constituency (Baba 2006).

In some cases, those who had won the primary elections were not ultimately selected. Instead, more prominent candidates were chosen by the management board. The party used customary methods of reconciliation to appease those who were eliminated. Conflicts were, in some cases, resolved amicably. ${ }^{6}$ This political strategy by the SDL highlights the use of both modern and customary institutions of society to not only win elections, but also to maintain internal party peace in the process of electioneering.

\section{Strategic Vanua Alliance}

In 2006, the SDL considered the support of chiefs as fundamental to the success of the party, even if they did not compete as candidates. Chiefs, as traditional political leaders, are often nominated as office bearers in Fijian political parties. President of the SDL Ratu Kalokalo Loki, for example, is Tamavua high chief, who, through his chiefly influence, is able to attract people from the vanua in Naitasiri to the party. ${ }^{7}$

Furthermore, an addition to the new cabinet, appointed through the Senate, was Bau and Kubuna high chief Adi Samanunu Talakuli Cakobau. She became minister without portfolio in the prime minister's office. The absence in government of any high-ranking Kubuna chief from Bau made Adi Samanunu's appointment a strategic one for maintaining the traditional balance of power and Kubuna support for the new SDL government. In addition, Adi Samanunu had been a strong rival to Qarase for the prime ministership back in July 2000, and one backed by the Speight group against the military's chosen candidate. Bringing her into the prime minister's office was designed to heal that rift, and to quash a potential source of ethno-nationalist opposition to the new multi-party cabinet arrangements.

6 In Dr Tupeni Baba's Samabula/Tamavua constituency, the second SDL candidate, Pita Nacuva, responded to his party listing him as second preference by urging supporters to vote below-the-line, much to the frustration of SDL campaign manager, Jale Baba. In the event, neither candidate was able to take this highly marginal seat, but Dr Baba was given an SDL Senate position, while Pita Nacuva became speaker of the house.

7 Tamavua is a vanua in the province of Naitasiri. The vanua owns much of the land at the northern end of Suva city. 
The Burebasaga fort has been maintained by the Minister for Education, Youth and Sports, Ro Teimumu Kepa, Roko Tui Dreketi (the leading title of the Burebasaga Confederacy). Her re-election, although hotly contested by her nephew, Ro Filipe Tuisawau, maintains some form of unity in Rewa (Saumaki 2007). The Tui Cakau, Ratu Naiqama Lalabalavu, head of the Matanitu Tovata or Tovata Confederacy, won in the Cakaudrove West Fijian Provincial Communal constituency. His cousin and traditional competitor to the Tui Cakau title, leader of the New Alliance Party of Fiji (NAPF), Ratu Epeli Ganilau lost in the Suva City Open constituency. The Tui Cakau's inclusion in cabinet is intended to ensure the support of the Cakaudrove Confederacy.

On Viti Levu, Tui Namosi Ratu Suliano Matanitobua's re-election highlighted the support of the Namosi people for the SDL government. The SDL's hold on Fijians in western Viti Levu was strengthened by the inclusion of chiefs like Ratu Meli Saukuru of Nadi, who was formerly vice president of the Methodist Church of Fiji, as well as Nadroga chief Ratu Isikeli Tasere and Navosa chief Ratu Jone Navakamocea.

The SDL managed to win all of the 17 Fijian provincial communal seats and all six of the urban Fijian communal seats in the 2006 election. The party secured 80 per cent of indigenous Fijian votes. In some constituencies, chiefly leadership contests were exacerbated by modern leadership competition in party politics, as seen in the Rewa Provincial Fijian Communal constituency. The SDL won a smaller proportion of Fijian votes ( 56 per cent) in this constituency than in any other Fijian constituency. Ro Filipe Tuisawau, who stood as an independent candidate after failing to secure the SDL nomination, obtained 41 per cent of the Rewa vote, perhaps also indicating continuing political dissent in Rewa. Since 1974, when the Fijian Nationalist Party was formed by Sakeasi Butadroka, the province of Rewa has been the power base of the Fijian Nationalist Party. Both Ro Teimumu Kepa and Ro Filipe Tuisawau were from the same chiefly household (Durutalo 2000:87-88). Within Fijian society, political parties are more than institutions for democratic representation; they also serve as vehicles for continuing subtle yet powerful ancient rivalries.

The SDL faced sterner competition in the open constituencies, where eligible citizens from all communities vote together. Ethnic voting was still observable in the open constituencies. For example, SDL won in the constituencies where Fijians predominated, such as the Lomaivuna- 
Namosi-Kadavu Open constituency. The FLP, on the other hand, won in constituencies like Labasa Open, where Indians predominated. Where an Indo-Fijian was fielded as an SDL candidate in a constituency with a strong SDL power base, the Indo-Fijian candidate won. The two IndoFijian SDL candidates in the Ra Open constituency and the Cunningham Open constituency both won their seats. Likewise, Fijians standing for the FLP in areas with a strong FLP power base also won their seats. This was the case for Fijian candidates in the Macuata East Open and the Yasawa Nawaka Open constituencies.

Neither the SDL nor the FLP had the unchallenged ascendancy in the open constituencies that they enjoyed in the communal constituencies. The open constituencies were shared almost equally between the SDL and FLP parties. The SDL won 13 of the 25 seats, and the FLP won the rest. Competition in some marginal constituencies was intense. For example, in the Laucala Open constituency, the SDL won with a margin of only 11 votes $(7,856)$ over the FLP $(7,845)$ (Fiji Election Results 2006).

\section{Conclusion}

The SDL's victory demonstrated the continuing political importance of the Fijian orthodoxy of vanua, lotu and matanitu as a unifying ideology for indigenous voters. In this context, any attempt by the party to concurrently promote Fijian political paramountcy with multi-racial politics is a real challenge, unless non-Fijians readily accept the promotion of policies such as ' $50 / 50$ by 2020: the blueprint for affirmative action for indigenous Fijians and Rotumans' (Fiji Government 2002). As we have seen, the SDL attempted to present a multi-ethnic front in 2006 by including Indo-Fijians in its election line-up, and is likely to do so in future elections. ${ }^{8}$ The SDL's strategy of facilitating policies for Fijian development has been a reaction to the long-term demands by some Fijian resource owners for greater government support in the development of indigenous resources.

8 There were 19 Indo-Fijian SDL candidates in the Indian Communal constituencies and six in the open constituencies. Two of these candidates, Rajesh Singh, who stood in the Cunningham Open constituency, and George Shiu Raj, who stood in the Ra Open constituency, were successful in the election. 
The 2006 election reminds us that party politics for many indigenous Fijians is a means of expressing two sets of rights and demandsdemocratic and indigenous. Indigenous demands are being expressed through the electoral system against non-Fijian groups and as a means of extending ancient internal Fijian rivalries. In the long term, however, these indigenous demands may become problematic in a society of diverse sociopolitical and cultural realities, and the SDL's policies may, in the long term, be seen as offering solutions to some groups of indigenous Fijians only.

\section{References}

Ali, A. 1986. Political Change: 1874-1960. In B.V. Lal (ed.), Politics in Fiji. Sydney: Allen \& Unwin.

Baba, T. 2006. Interview with SDL candidate in the Samabula Tamavua Open constituency in the 2006 election. Suva, Fiji, 16 June.

Durutalo, A. 2000. Elections and the Dilemma of Indigenous Fijian Political Unity. In B.V. Lal (ed.), Fiji Before the Storm: Elections and the Politics of Development. Canberra: Asia Pacific Press, The Australian National University.

Durutalo, A.L. 2005. Of Roots and Offshoots: Fijian Political Thinking, Dissent and the Formation of Political Parties (1960-1999). PhD thesis, The Australian National University.

Fiji Election Results 2006. www.elections.gov.ff/results2006/constituencies/ 47.html

Fiji Government 2002. 50/50 By Year 2020: 20 Year Development Plan (20012020) For the Enhancement of Participation of Indigenous Fijians and Rotumans in the Socio-Economic Development of Fiji. Parliamentary Paper No. 73/2002. Suva: Government of Fiji.

Manifesto Summary 2001. Good Leadership for a Secure and Stable Fiji: Soqosoqo Duavata ni Lewenivanua, the SDL's Plan for Prosperous Fiji. Manifesto Summary, 8.

Saumaki, B. 2007. Bose Ni Vanua and Democratic Politics in Rewa. In J. Fraenkel and S. Firth (eds), From Election to Coup in Fiji: The 2006 Campaign and Its Aftermath. Canberra: ANU E Press, 213-24. 
This text is taken from Understanding Oceania: Celebrating the University of the South Pacific and its collaboration with The Australian National University, edited by Stewart Firth and Vijay Naidu, published 2019 by ANU Press, The Australian National University, Canberra, Australia.

doi.org/10.22459/UO.2019.09 